\title{
Phylogeny of Coccomyxa (Myxosporea: Myxidiidae) spp. with the description of a new species from Bathygobius cyclopterus (Gobiidae) in the northern Red Sea
}

\author{
Ariel Diamant, Asaf Lipshitz and Michal Ucko
}

Israel Oceanographic and Limnological Research Ltd., National Center for Mariculture, Eilat 88112, Israel

Key words: Coccomyxa jirilomi, Myxosporea, bile ducts, Bathygobius cyclopterus

\begin{abstract}
Two species of Coccomyxa Léger et Hesse, 1907, one of the least studied myxosporean genera, are reported from shallow coastal waters in the Gulf of Eilat, Red Sea, Israel. A new species, Coccomyxa jirilomi sp. n. is described from the spotted frillgoby Bathygobius cyclopterus (Valenciennes) (Gobiidae). It forms polysporous plasmodia that invade the liver and form packed clusters inside the bile ductules. Plasmodia also occur in the bile ducts and gall bladder of the host, attached to the epithelial lining or free floating in the bile. Infected hepatic bile ductules packed with plasmodia were partially occluded, with evidence of cholestasis, periductular fibrosis and pericholangitis. The mature spore is ellipsoid, has smooth valves and contains a single polar capsule with the polar filament arranged in 4-5 oblique coils. Spore dimensions are 9.0-11.3 $\times 5.0-7.0 \mu \mathrm{m}$. A second species, Coccomyxa sp., with smaller 7.6-9.6 $\times 4.2-5.2 \mu \mathrm{m}$ and more delicate spores, was found in the gall bladder of the rippled rockskipper, Istiblennius edentulus (Forster et Schneider) (Blenniidae). The small subunit (SSU) rDNA sequence analysis of both Coccomyxa species suggests that they are closely related to members of the genera Myxidium, Zschokkella and Auerbachia, whose members infect the gall bladder of marine fish.
\end{abstract}

Eight species have been described in the genus Coccomyxa Léger et Hesse, 1907 since it was established 100 years ago, and all are from marine fish hosts. Only one is histozoic, invading the gill cartilage (Cheung and Nigrelli 1990), while the others are coelozoic parasites of the gall bladder (e.g. Wu 1991, Lom and Dyková 1992, Sarkar 1995). Gall bladder-inhabiting myxozoans (e.g. Myxidium, Zschokkella, Ceratomyxa, Chloromyxum and Leptotheca species) have long been considered to have generally low significance as fish pathogens (Lom and Dyková 1992), but a few have considerable impact on their hosts (Walliker 1968, Feist and Bucke 1992, MacKenzie et al. 2005).

The currently available information on Coccomyxa is sparse and deals mostly with light microscopy descriptions of the spores. In this paper, we provide the first details on the phylogenetic status of Coccomyxa spp., using molecular tools. We report herein on two undescribed species from the Red Sea, one that parasitizes the hepatic bile ducts and gall bladder of the frillgoby Bathygobius cyclopterus (Valenciennes), for which the name Coccomyxa jirilomi sp. $\mathrm{n}$. is proposed, and the other from the rippled rockskipper Istiblennius edentulus (Forster et Schneider).

\section{MATERIALS AND METHODS}

Specimens of Bathygobius cyclopterus and Istiblennius edentulus were examined intermittently during the spring and summer months (April-September) of 2003-2005. The fish were caught in the shallow rocky intertidal waters in the Gulf of Eilat, Israel (Red Sea). Fish were kept in flowing sea water and examined within one week of capture. Specimens were measured, weighed, and dissected, with external surfaces and internal organs examined for presence of parasites and lesions. Parasites were examined in fresh mounts using phase contrast and Nomarski interference microscopy. Air-dried smears were stained with Giemsa method. Portions of gall bladder and liver tissue were fixed in $10 \%$ buffered neutral formalin and processed into paraffin blocks. Sections were stained with haematoxylin and eosin, or Gram and tartrazine (for strong contrast staining of spore polar capsules).

Samples of parasites and host tissue for molecular analysis were preserved in $90 \%$ ethanol or frozen and stored at $-80^{\circ} \mathrm{C}$ until processed.

DNA extraction. Samples for molecular analysis were ground with $300 \mu \mathrm{l}$ of grinding buffer $(100 \mathrm{mM}$ Tris- $\mathrm{HCl} \mathrm{pH}$ 9, $100 \mathrm{mM}$ EDTA, 1\% SDS) and incubated for $30 \mathrm{~min}$ at $70^{\circ} \mathrm{C}$. The homogenate was then placed on ice for $30 \mathrm{~min}$ with $42 \mu \mathrm{l}$ of $8 \mathrm{M}$ potassium acetate and centrifuged twice at $12,000 \mathrm{~g}\left(15 \mathrm{~min}\right.$ and $5 \mathrm{~min}$ at $\left.4^{\circ} \mathrm{C}\right)$. DNA was precipitated with 1 volume of isopropanol for $15 \mathrm{~min}$ at room temperature, washed twice with $70 \%$ ethanol and left to be air-dried. Pel-

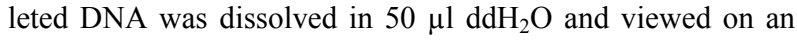
agarose gel $(0.7 \%)$ stained with ethidium bromide. Quantity and purity of DNA extraction were estimated using a RNA/ DNA Calculator (Gene Quant pro, Amersham, Cambridge, England).

Polymerase Chain Reaction. PCR reactions were performed in a Programmable Thermal Controller (PTC-100TM, MJ Research, San Francisco, California). Total volume of PCR reactions was $25 \mu$, containing: $0.5 \mathrm{U}$ of Taq DNA polymerase (Promega, Madison, Wisconsin), PCR buffer (10 $\mathrm{mM}$ Tris- $\mathrm{HCl}$ (pH 9.0), $50 \mathrm{mM} \mathrm{KCl}$ and $0.1 \%$ Triton $\mathrm{X}-100$ ), $1.5 \mathrm{mM} \mathrm{MgCl}_{2}$, deoxynucleotide triphosphates, each at a final 
Table 1. Primers used in the current study.

\begin{tabular}{l|lc}
\hline \multicolumn{1}{c|}{ Name } & \multicolumn{1}{c}{ Sequence 5' ' $^{\prime}$} & Location according to AY673966 \\
\hline $18 \mathrm{e}^{\mathrm{a}}$ & CTG GTT TGA T TC TGC CAG T & \\
Myx393-R & GCGCAAAT TACCCAACC AG & $396-415$ \\
CocF1 & CCC ACC AAA GAC TCA CTA ATG C & $873-894$ \\
Ent894-F & GAC TCA CTA ATG CGA AAG C $G$ & $882-901$ \\
CocR2 & GGC AAC TCA CCA GGT CCA & $1152-1169$ \\
CocR1 & GTC CCT ATT TGA TTA CGA CTG & $1289-1309$ \\
$18 \mathrm{~g}^{\mathrm{a}}$ & CAC ACC GCC CGT CGC TAG TAC CG & \\
\hline
\end{tabular}

${ }^{a}$ Hillis and Dixon $1991 .{ }^{b}$ These primers were originally designed for Enteromyxum leei; in the case of primer Ent894-F in Coccomyxa sequence the last base (G) is A.

concentration of $0.2 \mathrm{mM}, 6.5 \mathrm{pmol}$ of each primer and 5-50 ng genomic DNA. Typical cycling parameters included: $1 \mathrm{~min}$ at $95^{\circ} \mathrm{C}, 1 \mathrm{~min}$ at $55^{\circ} \mathrm{C}$, and $1.5 \mathrm{~min}$ at $72^{\circ} \mathrm{C}$, for 36 cycles. The initial denaturation step was extended to $5 \mathrm{~min}$ and the final extension step to $10 \mathrm{~min}$.

Oligonucleotide primers. To avoid amplification of host DNA, amplifications were carried out using a combination of the universal primers 18e and $18 \mathrm{~g}$ (Hillis and Dixon 1991) paired with myxosporean specific primers designed on the basis of published sequences available in the GenBank, and preliminary sequences of Coccomyxa samples (Table 1): 18eEnt894F, 18e-CocR1, CocF1-18g, 18e-CocR2 and Ent894F$18 \mathrm{~g}$.

Sequencing. PCR products were purified prior to sequencing, using QIAquick PCR purification kit (QIAGEN, Hilden, Germany). For sequencing, all seven primers listed in Table 1 were used. Sequencing reactions were performed with an Automated DNA Sequencer (Perkin Elmer Co. Model 3700, Norwalk, CT, USA) using an ABI PRISM ${ }^{\mathbb{R}}$ BigDye $^{\text {TM }}$ Terminator Cycle Sequencing Ready Reaction Kits (Applied Biosystems), by the DNA Sequencing Biological Services Unit, Weizmann Institute, Rehovot, Israel.

Phylogenetic analyses. The SSU rDNA sequences, determined for two species of Coccomyxa, were aligned with 24 sequences retrieved from the GenBank. The dataset included sequences determined for marine myxosporeans that are over $1,500 \mathrm{bp}$ in length.

Sequences were aligned using Clustal_W (Thompson and Higgins 1994) and required no subsequent editing. Tetracapsuloides bryosalmonae was used as an outgroup (Jirků et al. 2006). Maximum parsimony (MP) trees were constructed with PAUP* version 4.0b10 (Swofford 1998), heuristic search with tree-bisection-reconnection (TBR) branch swapping, random addition of sequences (100 replications) and stepwise-addition starting trees. Maximum likelihood (ML) analyses were used to validate the phylogenetic relationship inferred from the MP analyses. HKY85 settings were used for heuristic search by ML partition, in which gamma shape distribution, base frequencies and $\mathrm{Ts} / \mathrm{Tv}$ ratio were all based upon tree topology. Nodal support was assessed by bootstrap re-sampling; 1,000 replicates by MP and 100 by ML.

\section{RESULTS}

Myxosporean plasmodia and spores were found in the gall bladder and hepatic bile ducts in B. cyclopterus, while in I. edentulus, infections were only observed in the gall bladder.

\section{Coccomyxa jirilomi sp. $\mathrm{n}$.}

Figs. 1-9, 12-19

Bathygobius cyclopterus harboured myxosporean plasmodia, roughly $40-120 \mu \mathrm{m}$ in length, in the hepatic bile ducts and/or gall bladder. Based on spore morphology (Figs. 1-5), the myxosporean was placed in the genus Coccomyxa Léger et Hesse, 1907.

Spores. Mature spore ellipsoid in frontal view, slightly rounded in sutural view (Figs. 1-4). Valves approximately equal in size, smooth, with fine suture difficult to discern in fresh material, evident in Giemsastained spores (Fig. 3). Single, pyriform to ovoid polar capsule positioned at one pole of spore. Length of polar capsule approximately 1.9 times width; polar filament arranged in 4-5 coils. Sporoplasm located in spore cavity, adjoining polar capsule (Fig. 4a). In a distinctive configuration, basal portion of filament extends from apex of polar capsule, drops to mid capsule level, loops and re-ascends to form first filament coil (Fig. 4b). Extruded filament long, measuring $>100 \mu \mathrm{m}$ in Giemsastained smears (Fig. 5). Measurements of fresh spores from gall bladders of 2 host individuals $(\mathrm{n}=30, \mu \mathrm{m})$ : length $10.1 \pm 0.8$ (range 9.0-11.3), width $6.1 \pm 0.5$ (range: 5.0-7.0), polar capsule $5.1 \pm 0.4 \times 2.7 \pm 0.3$ (range 3.5-5.7 × 1.9-3.2).

Plasmodia. Polysporous, occurring in the hepatic bile vessels or gall bladder. In the bile ductules, packed together, often forming cluster that partially or completely obstructed the lumen and tightly adjoined the surrounding epithelial lining (Fig. 6). Individual size of plasmodium difficult to estimate in packed clusters. In wide biliary ductules, bile ducts and gall bladder, individually attached plasmodia bordering epithelial lining measured 40-120 $\mu \mathrm{m}$ in diameter (Fig. 7). Mixed infections of Coccomyxa jirilomi together with an unidentified species of Ceratomyxa, with smaller plasmodia, occurred in the gall bladder (Figs. 7, 8). Host cell debris, plasmodium fragments and free spores were often observed floating freely in gall bladder (Fig. 9). Infections of $C$. jirilomi in the gall bladder were commonly accompanied by an unidentified hyperparasitic microsporidian (see Fig. 1, arrowed).

Type and on ly host: Spotted frillgoby, Bathygobius cyclopterus (Valenciennes, 1837) (Gobiidae).

Ty pe loc a lity: Eilat, Red Sea, Israel. 

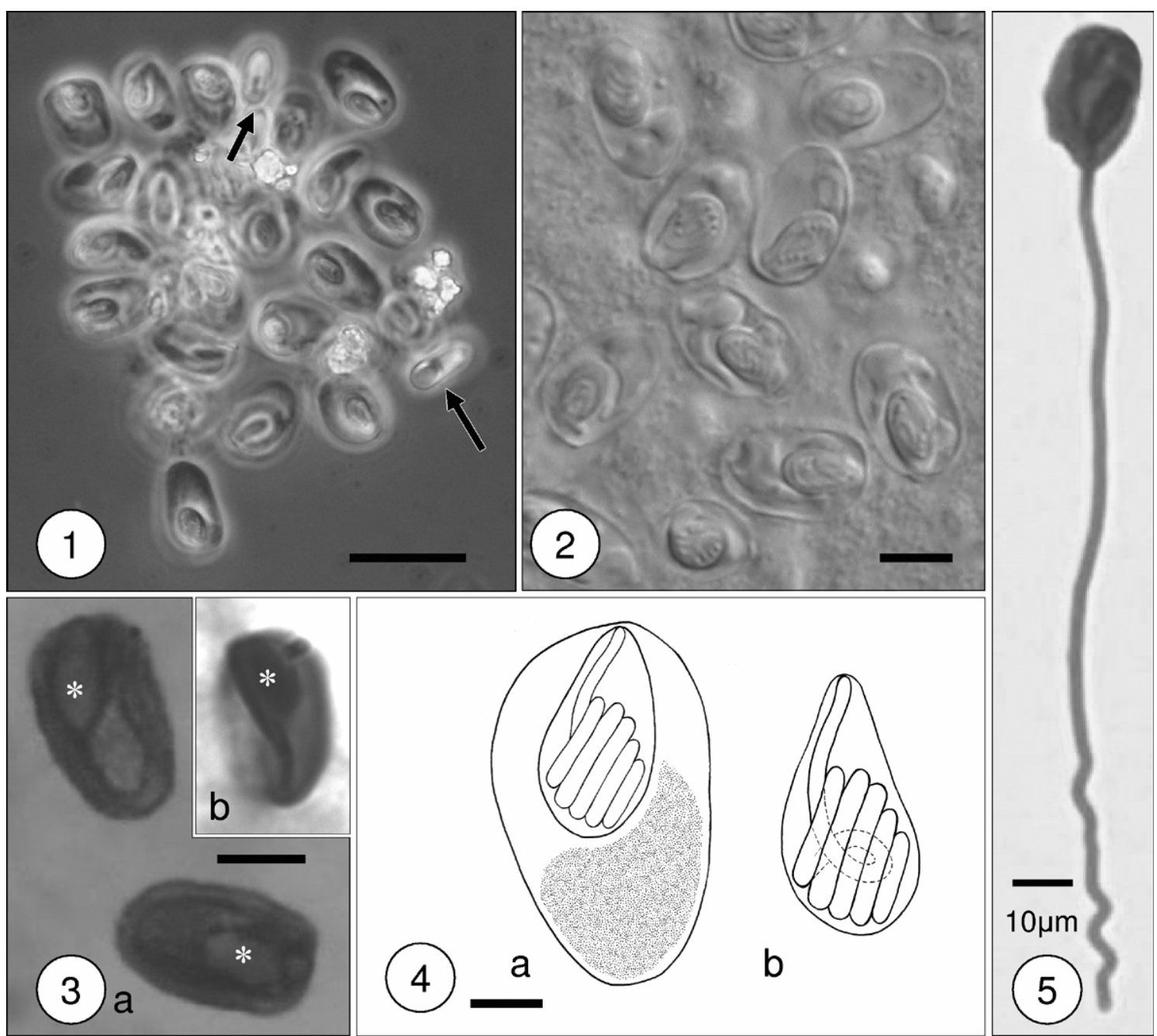

b

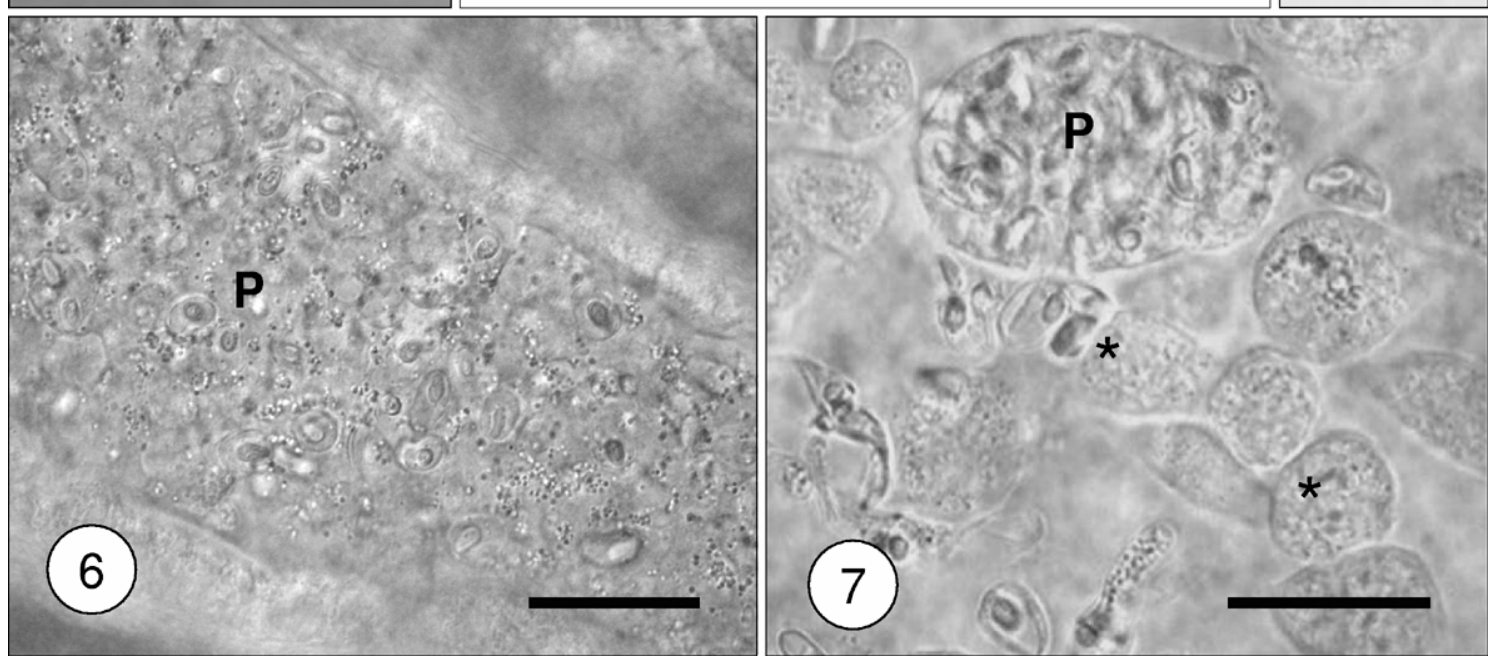

Figs. 1-7. Coccomyxa jirilomi sp. n. in Bathygobius cyclopterus. Fig. 1. Spores in fresh bile; arrows show microsporidian spores (phase contrast). Fig. 2. Spores in fresh bile (Nomarski interference microscopy). Fig. 3. Spores in air dried smear of bile. a front view; $\mathbf{b}$ - side view; * - polar capsule (Giemsa). Fig. 4. Line drawing of fresh spore. a - front view; $\mathbf{b}$ - diagram of filament configuration in polar capsule. Fig. 5. Spore with ejected polar filament in air-dried bile smear (Giemsa). Fig. 6. Fresh squash preparation of liver, showing polysporous plasmodium $(\mathrm{P})$ in the lumen of a hepatic bile ductule. Fig. 7. Polysporous plasmodium $(\mathrm{P})$ and spores of $C$. jirilomi in a fresh bile mount. Small plasmodia $\left(^{*}\right)$ probably belong to a coexisting infection with Ceratomyxa (phase contrast). Scale bars: Fig. $1=15 \mu \mathrm{m}$; Figs. $2,3=5 \mu \mathrm{m}$; Fig. $4 \mathrm{a}=2 \mu \mathrm{m}$; Fig. $5=10 \mu \mathrm{m}$; Figs. $6,7=25$ $\mu \mathrm{m}$. 

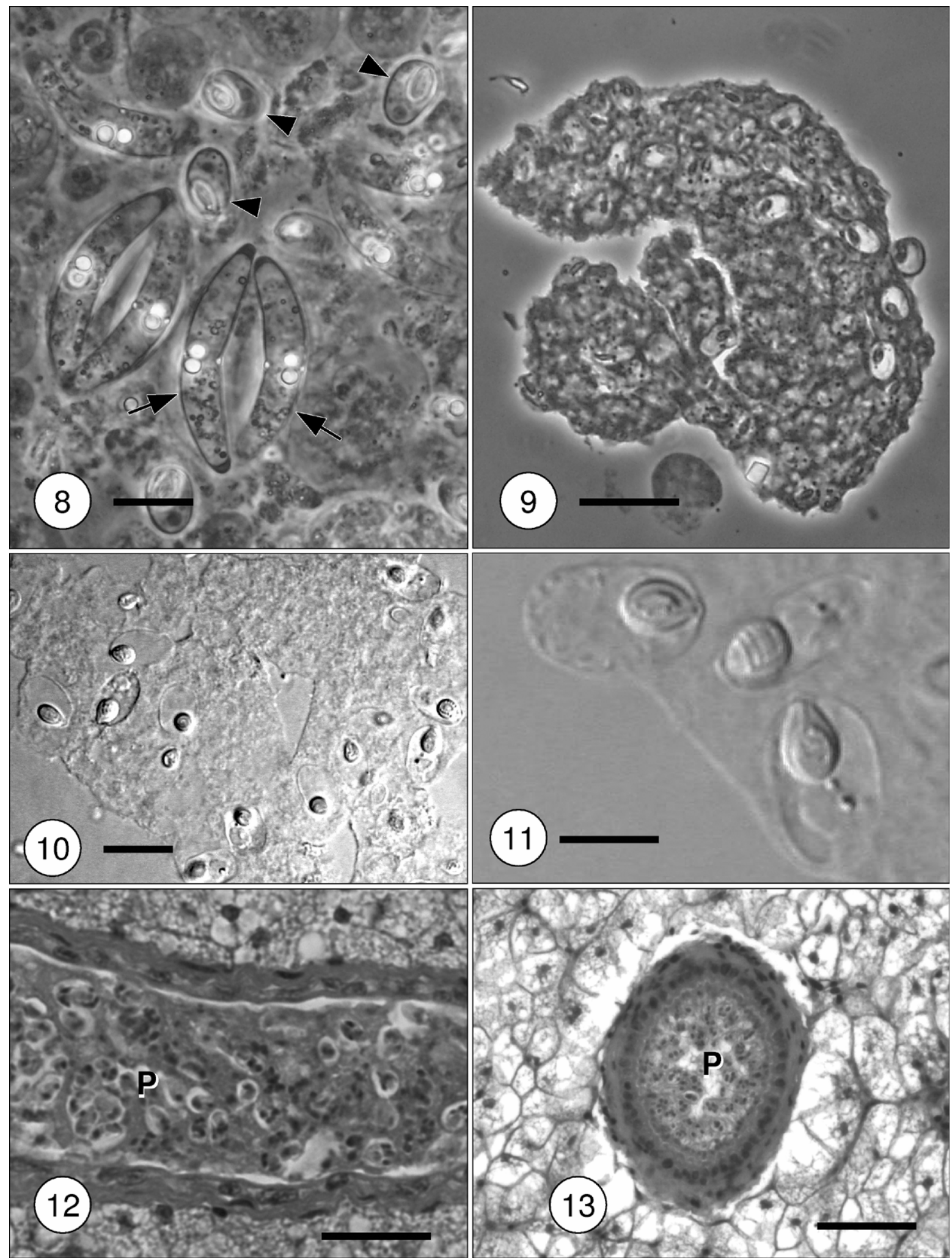

Fig. 8. Spores of Coccomyxa jirilomi sp. n. (arrowheads) and Ceratomyxa sp. (arrows) in a fresh bile smear from Bathygobius cyclopterus (phase contrast). Fig. 9. Partially disintegrated $C$. jirilomi plasmodium in a fresh bile smear from B. cyclopterus (phase contrast). Fig. 10. Fragment of polysporous plasmodium of Coccomyxa sp. from the gall bladder of Istiblennius edentulus (Nomarski). Fig. 11. Coccomyxa sp. spores from the gall bladder of $I$. edentulus (Nomarski). Fig. 12. Longitudinal section through hepatic bile ductule in B. cyclopterus, showing lodged C. jirilomi plasmodia (P) (H\&E). Fig. 13. Liver section showing C. jirilomi plasmodia (P) in a cross-section of bile ductule (H\&E). Scale bars: Figs. 8, $10=10 \mu \mathrm{m}$; Figs. 9, $12=25 \mu \mathrm{m}$; Fig. $11=$ $5 \mu \mathrm{m}$; Fig. $13=50 \mu \mathrm{m}$. 
Table 2. Isolates of Coccomyxa spp. sequenced in the current study.

\begin{tabular}{|c|c|c|c|c|c|c|}
\hline Species & Type & $\begin{array}{c}\text { GenBank } \\
\text { accession no. }\end{array}$ & Host & $\mathrm{bp}$ & No. & Date \\
\hline C. jirilomi sp.n. & BC200903 & DQ323044 & $\begin{array}{l}\text { Bathygobius } \\
\text { cyclopterus }\end{array}$ & 1577 & $\begin{array}{l}1 \\
2 \\
3\end{array}$ & $\begin{array}{l}20 / 09 / 2003 \\
29 / 04 / 2005 \\
05 / 05 / 2005\end{array}$ \\
\hline Coccomyxa sp. & IE200903 & DQ323043 & $\begin{array}{l}\text { Istiblennius } \\
\text { edentulus }\end{array}$ & 1578 & $\begin{array}{l}4 \\
5 \\
6\end{array}$ & $\begin{array}{l}20 / 10 / 2003 \\
28 / 10 / 2003 \\
27 / 11 / 2005\end{array}$ \\
\hline
\end{tabular}

S i t e of infection: Hepatic bile ducts and gall bladder.

P r e v a 1 e n c e : $33.3 \%$ (8 fish, $4.1-9.1 \mathrm{~mm}$ total length (TL), of 24 fish examined).

T y p e mat e r i a 1: Specimens deposited in the Institute of Parasitology, Academy of Sciences of the Czech Republic, České Budějovice; syntype, DPF-010, air-dried Giemsastained spores.

E t y m o lo g y: The species is named in honour of Dr. Jiří Lom, distinguished Czech fish parasitologist, in recognition of his exceptional contribution to the knowledge of the Myxozoa.

\section{Coccomyxa sp.}

Figs. 10, 11

Spores of Coccomyxa sp., distinct from C. jirilomi, were found in the gall bladder of 3 of $25(12 \%) 8-19$ $\mathrm{mm}$ (TL) individuals of Istiblennius edentulus. Unfortunately, since infection intensities were low, insufficient material was available for a thorough study; thus, we prefer not to describe it as a new species at this time. Its plasmodia were polysporous (Fig. 10), with oval spores (Fig. 11) of $8.4 \times 4.7 \mu \mathrm{m}$ mean length and with $3.5 \times$ $2.4 \mu \mathrm{m}$ polar capsule, which is smaller than $C$. jirilomi. The drop-shaped polar capsule had 5-6 filament coils. The sutures of the fine and very thin spore valves could not be discerned with light microscope. The SSU rDNA sequence of this species displayed $96.5 \%$ nucleotide sequence homology with $C$. jirilomi. It is noteworthy that despite the significant overlap in their hosts' Red Sea shallow-water habitats, $C$. jirilomi was found exclusively in B. cyclopterus, while Coccomyxa sp. only in $I$. edentulous; thus, both display considerable host specificity.

\section{Molecular phylogeny}

Overall, SSU sequences were determined for six samples. These were obtained from the two host species, B. cyclopterus and I. edentulus. Each host individual was recovered in the course of a different sampling event. These samples revealed two distinct sequences of Coccomyxa; type BC200903 from B. cyclopterus (referred to as Coccomyxa jirilomi) and type IE200903 from I. edentulus (referred to as Coccomyxa sp.). Both types were submitted to GenBank (Table 2), and as indicated above, displayed a 96.5\% rDNA nucleotide sequence homology.

Alignment of the complete datasets revealed 742 parsimony-informative characters, a single tree for each of the algorithms used (MP and ML). Estimated ML parameters were: base frequencies $=\mathrm{A}: 0.255736 \mathrm{C}: 0.194$
074 G:0.248568 T:0.301622, ti $/ \mathrm{tv}$ ratio $=1.563265$ $(\mathrm{kappa}=3.200426)$ and gamma shape parameter $=$ 0.323341 .

The phylogenetic analysis produced a clear topology of five distinct and well-defined branches, supported by high bootstrap values calculated for both algorithms. The branches were characterized as: Ceratomyxa clade, Enteromyxum clade, Kudoa clade (outlier Unicapsula sp.), Parvicapsula clade (outlier Zschokkella lophii) and a mixed branch that includes representatives of five genera: Auerbachia, Coccomyxa, Ellipsomyxa, Myxidium and Zschokkella. Both species of Coccomyxa clustered together on a distinct and well-defined clade within this branch (Fig. 21).

\section{Pathogenesis}

A noticeable hypertrophic gall bladder containing a dark-green bile fluid was observed in some of the infected B. cyclopterus; no apparent gross changes were seen in the liver, however. In squash preparations, plasmodia and spores could be observed in the parasitized bile ductules (Fig. 6). In histological sections, the overall appearance of the hepatic parenchyma appeared mostly normal. Nevertheless, infected ductules packed with plasmodia were partially occluded, with evidence of cholestasis, some compression flattening of the epithelial lining and minor periductular fibrosis (Figs. 12-20). Although the infected ducts remained intact, lumen dilatation was evident and in some cases also infiltration of inflammatory cells (pericholangitis). Degenerative vacuolation of parenchymal cells adjacent to the obstructed ductules was also observed (Fig. 18). No plasmodia or spores were found in the liver parenchyma, and pancreatic tissue displayed no perceptible changes.

A hyperparasitic microsporidian, tentatively identified as belonging to the genus Glugea, was observed to infect Coccomyxa jirilomi plasmodia in B. cyclopterus (see Diamant 2005). No microsporidians were found in any of the $I$. edentulus individuals examined.

\section{DISCUSSION}

\section{Identity of the species}

The eight species of Coccomyxa described so far occur in diverse zoogeographical localities and a variety of hosts; Coccomyxa jirilomi being the first to be described from the Red Sea (Table 3). Coccomyxa jirilomi differs from all previously described members of the genus. Its spore is smaller than C. morovi and C. ovale, and it has 

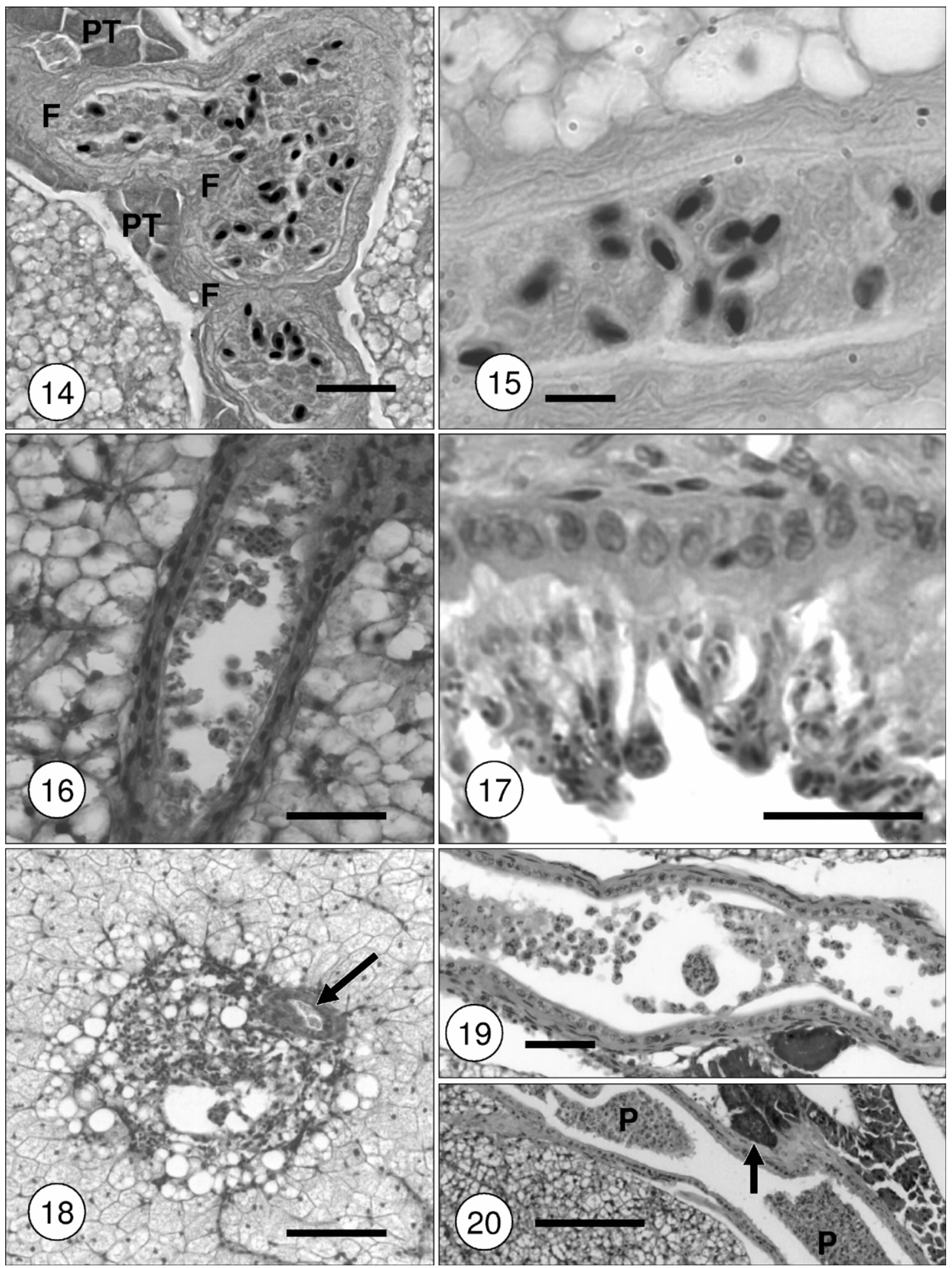

Figs. 14-20. Histological sections of Bathygobius cyclopterus liver parasitized by Coccomyxa jirilomi sp. n. Fig. 14. Section at bifurcation of hepatic bile ductule, exhibiting dark polar capsules of mature spores. Note fibrosis (F) and associated islets of pancreatic tissue (PT) (Gram and tartrazine). Fig. 15. High-power magnification of section through ductule packed with sporulating plasmodia (Gram and tartrazine). Fig. 16. Plasmodia attached to epithelial lining of narrow bile duct (H\&E). Fig. 17. Plasmodia attached to epithelial lining of large bile duct (H\&E). Fig. 18. Inflammatory cell infiltration in an area of the liver adjoining a parasitized bile ductule (arrow). Note degenerative hepatic parenchyma cells and vacuolation (H\&E). Fig. 19. Duct displaying both distinct and packed plasmodia (H\&E). Fig. 20. Cystic duct near region where it exits the liver. P - plasmodia; dark area (arrow) - a pancreatic islet (H\&E). Scale bars: Figs. 14, $20=100 \mu \mathrm{m}$; Fig. $15=10 \mu \mathrm{m}$; Figs. 16, 17, $19=50 \mu \mathrm{m}$; Fig. $18=40$ $\mu \mathrm{m}$. 


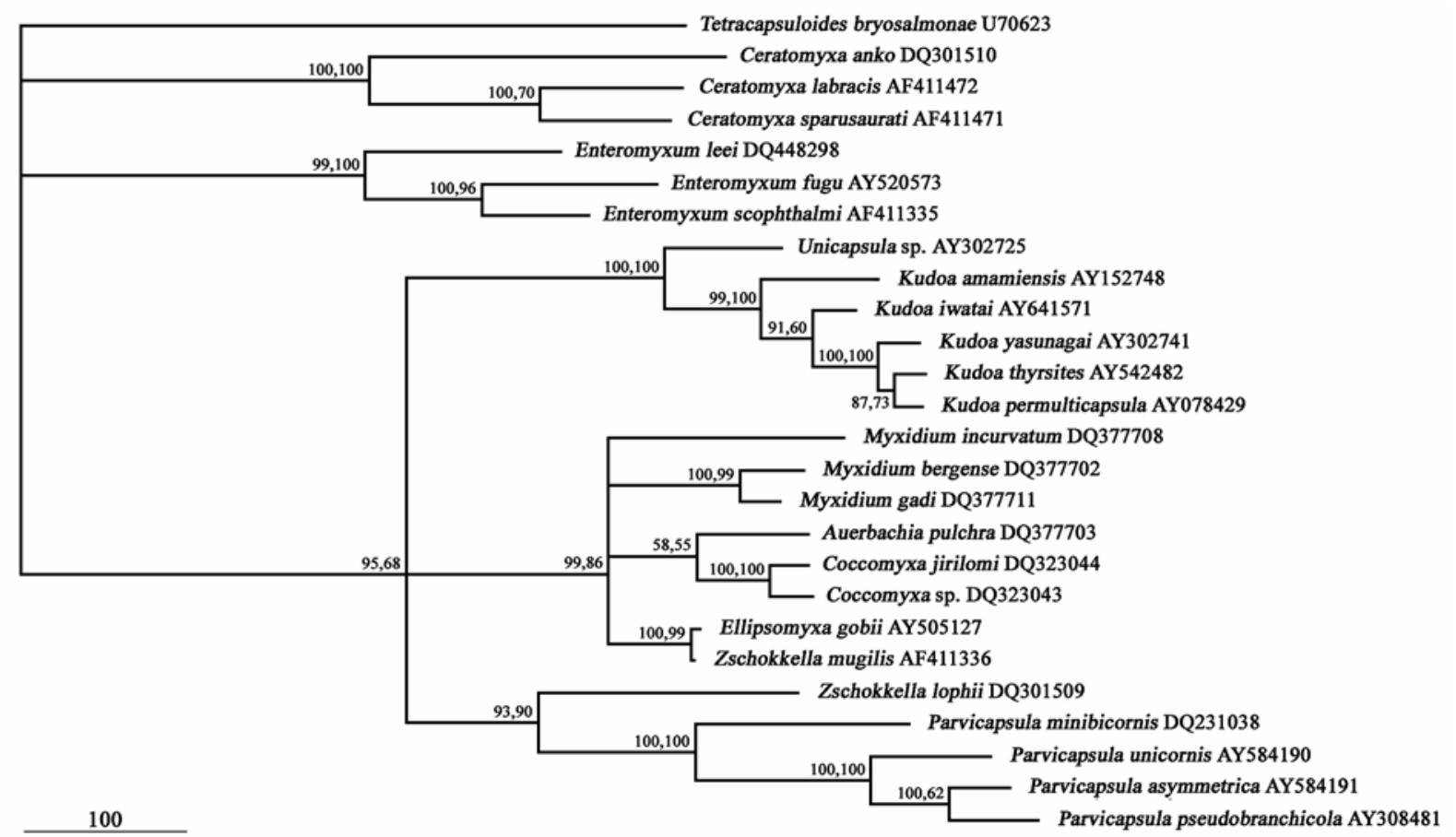

Fig. 21. Maximum parsimony of the marine linage within the Myxosporea (strict consensus of 6 trees). Nodes were fully forked only if they appear on the ML tree as well. Bootstrap values represent 1,000 repetitions with MP (left) and 100 repetitions with ML (right).

Table 3. List of named species of Coccomyxa Léger et Hesse, 1907.

\begin{tabular}{|c|c|c|c|c|}
\hline Coccomyxa species & $\begin{array}{c}\text { Host species } \\
\text { (common name) }\end{array}$ & Geographic locality & Infection site & Source \\
\hline $\begin{array}{l}\text { C. morovi } \\
\text { Léger et Hesse, } 1907\end{array}$ & $\begin{array}{l}\text { Sardina pilchardus } \\
\text { (pilchard) }\end{array}$ & $\begin{array}{l}\text { Mediterranean, } \\
\text { Celtic Sea }\end{array}$ & Gall bladder & Léger and Hesse 1907 \\
\hline $\begin{array}{l}\text { C. claviforme } \\
\text { Cunha et Fonseca, } 1919\end{array}$ & $\begin{array}{l}\text { Chilomycterus spinosus } \\
\text { (porcupinefish) }\end{array}$ & Atlantic (Brazil) & Gall bladder & Cunha and Fonseca 1919 \\
\hline $\begin{array}{l}\text { C. ovale Kovaleva et } \\
\text { Gaevskaya, } 1988\end{array}$ & $\begin{array}{l}\text { Beryx splendens } \\
\text { (Alfonsino) }\end{array}$ & Atlantic & Gall bladder & Kovaleva and Gaevskaya 1988 \\
\hline $\begin{array}{l}\text { C. hoffmani Cheung et } \\
\text { Nigrelli, } 1990\end{array}$ & $\begin{array}{l}\text { Plotosus anguillaris } \\
\text { (coral catfish) }\end{array}$ & $\begin{array}{l}\text { Aquarium specimen } \\
\quad \text { (ex Pacific) }\end{array}$ & Gill cartilage & Cheung and Nigrelli 1990 \\
\hline $\begin{array}{l}\text { C. leiognatha } \\
\mathrm{Wu}, 1991\end{array}$ & $\begin{array}{l}\text { Leiognathus brevirostris } \\
\text { (ponyfish) }\end{array}$ & South China Sea & Gall bladder & Wu 1991 \\
\hline $\begin{array}{l}\text { C. meridiei } \\
\text { Lom, Rohde et Dyková, } 1992\end{array}$ & $\begin{array}{l}\text { Herklotsichthys castelnaui } \\
\text { (silver herring) }\end{array}$ & Pacific (Australia) & Gall bladder & Lom et al. 1992 \\
\hline $\begin{array}{l}\text { C. tenuiparies } \\
\text { Lom, Rohde et Dyková, } 1992\end{array}$ & $\begin{array}{l}\text { Heteroclinus whiteleggii } \\
\text { (weedfish) }\end{array}$ & Pacific (Australia) & Gall bladder & Lom et al. 1992 \\
\hline $\begin{array}{l}\text { C. baleswarensis } \\
\text { Sarkar, } 1995\end{array}$ & $\begin{array}{l}\text { Hilsa ilisha } \\
\text { (shad) }\end{array}$ & Indian Ocean & Gall bladder & Sarkar 1995 \\
\hline C. jirilomi sp. $\mathrm{n}$. & $\begin{array}{l}\text { Bathygobius cyclopterus } \\
\text { (spotted frillgoby) }\end{array}$ & Red Sea & $\begin{array}{l}\text { Gall bladder, } \\
\text { bile ducts }\end{array}$ & Present study \\
\hline
\end{tabular}

fewer filament coils in the polar capsule than both species; C. claviforme, C. baleswarensis and C. leiognatha also have larger spores. $C$. hoffmani has a smaller spore than $C$. jirilomi and parasitizes gill cartilage. C. tenuiparies has the spore about the same size as $C$. jirilomi, but it is wider, the polar filament has more coils, and the plasmodium is mono- or disporous. C. meridiei is morphologically most similar to $C$. jirilomi in spore size, and both species have the unique polar filament configuration in which the basal part of the filament extends deeper than the mid-capsule length before turning back to form the first coil. However, C. meridiei has more filament coils (5-7), its polar capsule is pyriform and the spore valves are unequal, with the smaller not reaching the posterior pole of the spore. Also, its plasmodium is different, described as oval, flat and measuring up to $600 \times 200 \mu \mathrm{m}$ (Lom et al. 1992). Coccomyxa jirilomi is the only species of the genus thus far reported to invade its host's hepatic bile ducts. On the basis of the above mentioned different morphological features, the distinct host species, target site and different biogeographical distribution, we consider it as a new spe- 
cies. Observations on its ultrastructure will be published separately (Diamant, Lipshitz and Ucko, in preparation).

The repeat sequences obtained from the distinct isolates BC200903 and IE200903 represent two closely related and host species-specific myxosporean species, Coccomyxa jirilomi found exclusively in Bathygobius cyclopterus and Coccomyxa sp. in Istiblennius edentu$l u s$, respectively. It is remarkable that no cross infections were observed, since the hosts share the same littoral Red Sea habitat.

The pathogenicity of Coccomyxa species is generally low. The only member of the genus which has been reported to harm its host is $C$. hoffmani, which causes compression damage to branchial cartilage and associated capillaries as well as lamellar erosion (Cheung and Nigrelli 1990). Coccomyxa jirilomi may adversely affect function of the host intra-hepatic biliary system, resulting in pericholangitis and degeneration of the parenchyma, particularly at the periphery of partially or fully obstructed bile ductules. However, in most cases pathogenesis was negligible and never reached the stage of pathology observed in liver infections of related myxosporeans, such as Zschokkella nova or Z. icterica (Bucher et al. 1992, Diamant and Paperna 1992).
In our phylogenetic analysis, the two Coccomyxa species formed a new, well-defined clade within one of the five marine lineages of Myxosporea recently outlined in detail by Fiala (2006). Originally, this genus was assigned as a member of the Myxidiidae Thélohan, 1892, which concurs with our finding of $C$. jirilomi and Coccomyxa sp. being sister to Myxidium, Zschokkella, Ellipsomyxa and Auerbachia. Consequently, molecular data support the inclusion of Coccomyxa in the family Myxidiidae Thélohan, 1892, suborder Variisporina Lom et Noble, 1984, as based on spore morphology. It may be expected that the relationship between various taxa within the Myxidiidae will become clearer as the SSU rDNA and more genes of additional species are sequenced.

Acknowledgements. This study was carried out at the GreenKeiser Fish Health Center of the National Center for Mariculture, IOLR, Eilat. We acknowledge the generous support of the Green family (Haverford, PA, USA) and thank Dr. Ivan Fiala (Institute of Parasitology, České Budějovice, Czech Republic) for allowing us to include as yet unpublished sequences of Myxidium and Auerbachia in our analysis. We also thank Barbara Colorni for preparation of the histological specimens.

\section{REFERENCES}

Bucher F., Hofer R., El-Matbouli M. 1992: Prevalence and pathology of Zschokkella nova (Myxosporea) in the liver of bullhead Cottus gobio from a polluted river. Dis. Aquat. Org. 14: 137-143.

Cheung P.J., Nigrelli R.F. 1990: Coccomyxa (Myxosporea: Bivalvulida) and Septemcapsula (Myxosporea: Multivalvulida) infections, the possible cause of death of coral catfish Plotosus anguillaris in captivity. J. Aquat. Anim. Health 2: $112-118$.

CUNHA DA A.M., FONSECA DA O. 1919: Sobre os Neosporides parasitos dos peixes do Brazil. Braz. Med. 37: 81.

DIAMANT A. 2005: Fish hyperparasitic microsporidian-myxosporean systems from the Red Sea. Folia Parasitol. 52: Abstract $2 \mathrm{~A}$.

DIAMANT A., PAPERNA I. 1992: Zschokkella icterica sp. nov. (Myxozoa, Myxosporea) a pathogen of wild rabbitfish $\mathrm{Si}$ ganus luridus (Ruppell, 1829) from the Red Sea. Eur. J. Protistol. 28: 71-79.

FEIST S.W., BUCKE D. 1992: Myxidium gadi Georgevitch, 1916 infections in saithe Pollachius virens L. from the North Sea. Bull. Eur. Assoc. Fish Pathol. 12: 211-214

FIALA I. 2006: The phylogeny of Myxosporea (Myxozoa) based on small subunit ribosomal RNA analysis. Int. J. Parasitol. 36: $1521-1534$.

HiLlis D.M., DiXON M.T. 1991: Ribosomal DNA - molecular evolution and phylogenetic inference. Q. Rev. Biol. 66: 410 453.

JiRKŮ M., BOLEK M.G., WhIPPS C.M., JANOVY J. JR., KENT M.L., MODRÝ D. 2006: A new species of Myxidium (Myxosporea: Myxidiidae), from the western chorus frog, Pseudacris triseriata triseriata, and Blanchard's cricket frog, Acris crepitans blanchardi (Hylidae) from eastern Nebraska: morphology, phylogeny and critical comments on amphibian Myxidium taxonomy. J. Parasitol. 92: 611-619.
Kovaleva A.A., Gaevskaya A.V. 1988: Myxosporidia (Protozoa, Myxosporea) of Beryx splendens from the Atlantic Ocean. Parazitologiya 22: 250-254.

LEGER L., HeSSE E. 1907: Sur une nouvelle Myxosporidia parasite de la sardine. C. R. Acad. Sci. Paris 145: 85-87.

LOM J., DYKOVÁ I. 1992: Protozoan Parasites of Fishes. Elsevier, Amsterdam, 315 pp.

LOM J., ROHDE K., DYKOVÁ I. 1992: Studies on protozoan parasites of Australian fishes I. New species of Coccomyxa Léger et Hesse, 1907, Ortholinea Shulman, 1962 and Kudoa Meglitsch, 1947. Folia Parasitol. 39: 289-306.

MacKenzie K., Kalavati C., GaArd M., Hemmingsen W. 2005: Myxosporean gall bladder parasites of gadid fishes in the North Atlantic: their geographical distributions and an assessment of their economic importance in fisheries and mariculture. Fish. Res. 76: 454-465.

SARKAR N.K. 1995: A new Myxozoan, Coccomyxa baleswarensis n. sp. (Myxosporea: Myxidiidae), parasite in the gallbladder of an anadromous clupeid, Hilsa ilisha (Hamilton). Arch. Protistenkd. 145: 135-138.

SWOFFORD D.L. 1998: PAUP*. Phylogenetic analysis using parsimony (*and other methods). Version 4. Sinauer Associates, Sunderland, Massachusetts.

THOMPSON J.D., HIGGINS D.G. 1994: CLUSTAL_W: Improving the sensitivity of progressive multiple sequence alignment through sequence weighting, position-specific gap penalties and weight matrix choice. Nucl. Acids Res. 22: 4673-4680.

WALLIKER D. 1968: Studies on Myxidium oviforme, a myxosporidian parasite of Irish salmon, Salmo salar. Parasitology 58: 839-844.

Wu Z. 1991: The new species Coccomyxa leiognatha (Protozoa: Myxospora) from Leiognathus brevirostris. Trop. Oceanol. 10: $77-79$.

Accepted 19 January 2007 